\title{
Studi Analisa Synchronous Rectifier Buck Converter Untuk Meningkatkan Efisiensi Daya Pada Sistem Photovoltaic
}

\author{
Ari Robiul Ichsan ${ }^{* 1}$, Machmud Effendy $^{2}$, Diding Suhardi ${ }^{3}$ \\ 1,2,3 Universitas Muhammadiyah Malang \\ arirobiulichsan@gmail.com ${ }^{* 1}$, machmudefffendy@yahoo.com², diding@umm.ac.id ${ }^{3}$
}

\begin{abstract}
Abstrak
Abstrak-Sel surya atau sering disebut energi photovoltaic (PV) adalah energi yang saat ini popular karena PV yang sangat ramah terhadap lingkungan tetapi dalam pengaplikasiannya secara konvensional sistem PV juga banyak mengalami kekurangan terutama terhadap efisiensi daya keluaran yang terbilang rendah. salah satu faktor yang mempengaruhi terhadap efisiensi daya sistem PV yaitu pada bagian konverter DC-DC. Konverter DC-DC sebagai sumber daya sistem elektronika yang dapat ditingkatkan efisiensinya dengan cara mengganti dioda pada konverter DC dengan MOSFET. MOSFET dapat mengurangi rugi konduksi pada konverter DC sinkron karena rugi daya konduksi MOSFET lebih rendah dari rugi daya konduksi dioda. Pada perancangan ini sistem PV menggunakan konverter DC tipe penurun tegangan dengan menggunakan metode MOSFET sinkronisasi untuk menggantikan dioda pada rangkaian konverter DC tipe penurun tegangan atau juga disebut dengan synchronous buck converter. Kemudian akan dibandingkan efisiensi daya antara synchronous buck converter dengan nonsynchronous buck converter. Pada sistem PV menggunakan synchronous buck converter efisiensi daya yang dihasilkan ialah mencapai $98.47 \%$, sedangkan efisiensi daya yang dihasilkan pada non-synchronous buck converter disistem PV lebih rendah ialah $96.81 \%$. Ini membuktikan bahwa rugi konduksi pada MOSFET lebih rendah dibandingkan dengan rugi konduksi pada dioda.
\end{abstract}

Kata Kunci: DC Konverter, Efisiensi daya, MOSFET sinkronisasi, Photovoltaic (PV)

\begin{abstract}
Abstract- Solar cells or photovoltaic (PV) energy is a popular energy due to PV technology is renewable but in conventional application PV system has low output power efficiency. One factor which influenced the power efficiency of PV Systems that are in the DC-DC converter. Power efficiency in converter DC-DC can increase with replace diode to MOSFET. MOSFET can decrease the conduction loss of synchronous DC converter because conduction loss in MOSFET lower than diode. In this paper PV system is designed use DC converter buck converter type and synchronous MOSFET method or usually called synchronous buck converter. Power efficiency of synchronous buck converter is compare with non-synchronous buck converter. The result of power efficiency synchronous buck converter is $98.47 \%$, power efficiency of non-synchronous buck in PV system is $96.81 \%$. This analysis has proven the conduction losses in MOSFET lower than the conduction MOSFET in diode.
\end{abstract}

Keywords: Converter DC, Photovoltaic (PV), Power efficiency, synchronous MOSFET

\section{Pendahuluan}

Menipisnya sumber daya bahan bakar fosil di seluruh dunia, membuat kita diharuskan mencari sumber energi yang alternatif. Di antara semua pilihan energi terbarukan energi surya ialah energi yang paling bersih dan tidak ada habis-habisnya. Energi surya telah menawarkan solusi hasil yang menjanjikan dalam upaya tersebut. Solusi yang ditawarkan oleh energi surya sangat berpengaruh terhadap lingkungan tetapi dalam aplikasinya secara konvensional sel surya juga banyak mengalami kekurangan terutama pada sisi efisiensi keluaran yang terbilang rendah, hal tersebut dikarenakan perbedaan karakteristik antara sel surya dengan beban. Ada beberapa faktor yang mempengaruhi daya listrik yang dihasilkan oleh panel surya, seperti besarnya tingkat intensitas cahaya, suhu kerja dari panel surya dan kinerja dari konverter DC itu sendiri [1] [2] [3].

Ichsan, A., Effendy, M., \& Suhardi, D. (2017). Studi Analisa Synchronous Rectifier Buck Converter untuk Meningkatkan Efisiensi Daya pada Sistem PV. KINETIK, 2(3). doi:http://dx.doi.org/10.22219/kinetik.v2i3.201

Makalah dikirim 30 Juni 2017; Revisi 30 Juli 2017; Diterima 1 Agustus 2017 
Pada sel surya terdapat baterai yang biasanya digunakan, yakni baterai lead-acid, karena dapat diisi ulang sehingga sangat efisien pada sistem kelistrikan. Untuk mencegah kerusakan pada baterai, dibutuhkan sebuah alat pengendali yang dikenal dengan charge controller. Fungsi utama dari charge controller adalah mempertahankan keadaan baterai dengan mencegah terjadinya distribusi arus dan tegangan yang berlebihan pada baterai. Terdapat setidaknya dua jenis charge controller, yaitu menggunakan teknologi Pulse Width Modulation (PWM) dan Maximum Power Point Tracking (MPPT) [4] [5].

Menurut Dhananjay dan Anmol sebuah sistem Photovoltaic (PV) secara matematis yang terhubung dengan buck converter dengan algoritma Incremental Conductance (IC) untuk mengekstraksi daya maksimum pada kondisi PV yang berbeda. Mereka menyadari bahwa fungsi dasar dari DC-DC konverter di sistem PV adalah seperti daya proses yang mengubah tingkat antara arus dan tegangan sehingga daya maksimum dapat diekstraksi dari rangkaian PV [1].

Menurut Emmanuel dan Vasile perangkat semikonduktor memiliki kerugian konduksi karena terdapat tahanan yang aktif. Dioda yang terdapat pada buck converter memiliki forward voltage yang lebih tinggi dari sekitar $0,6 \mathrm{~V}$ sampai $0,7 \mathrm{~V}$ yang dapat mengalami kerugian daya dalam converter, dengan meningkatkan efisiensi dan kinerja yang lebih tinggi mereka melakukan desain terhadap buck converter dimana dioda diganti dengan Metal Oxide Semiconductor Field Effect Transistor (MOSFET) atau sering disebut synchronous rectifier (SR) buck converter, karena MOSFET digunakan untuk memenuhi efisiensi dan kinerja yang lebih tinggi. Mengganti dioda dengan MOSFET dapat meningkatkan efisiensi sampai 5\% atau lebih [6] [7].

Pada peneliti sebelumnya menurut Sutedjo, dkk mereka melakukan rancang bangun DCDC converter dengan pengendali PI yang mendapatkan efisiensi maksimum pada buck converter ialah $86,33 \%$ [8].

Ling-Feng Shi dan Wei-Gang Jia melakukan eksperimen terhadap synchronous buck DC-DC converter dengan menggunakan kontrol PWM dan auto-switching PWM/standby. Mereka mendapatkan hasil efisiensi maksimal ialah 94\% [9] [10].

Peneliti yang bernama Trias, dkk membahas sistem yang berbeda ialah konverter arus searah ke arus searah tipe penaik tegangan dengan dan tanpa MOSFET sinkronisasi, mereka menyadari bahwa dalam praktiknya efisiensi daya pada converter DC-DC tipe penaik tegangan sinkronisasi MOSFET lebih tinggi dibandingkan dengan MOSFET tanpa sinkronisasi. Mereka menyimpulkan pada duty cycle $40 \%$ ke atas efisiensi daya yang dihasilkan akan terus meningkat dan meninggalkan nilai efisiensi daya pada konverter tipe penaik tegangan tanpa MOSFET sinkronisasi, total efisiensi keseluruhan sistem yang dihasilkan ialah 95\% [11].

Penelitian ini akan memaksimalkan efisiensi daya synchronous buck converter pada sistem PV lalu akan dibandingkan dengan kinerja dari non-synchronous buck converter yang akan disimulasikan ke software MATLAB-SIMULINK r2012b.

\section{Metode Penelitian \\ 2.1 Diagram Blok}

Sistem PV dengan penurun tegangan non-synchronous buck converter ditunjukkan Gambar 1 dan Gambar 2 ialah dengan menggunakan synchronous buck converter. Kedua sistem PV tersebut berfungsi menurunkan tegangan menjadi $12 \mathrm{~V}$.

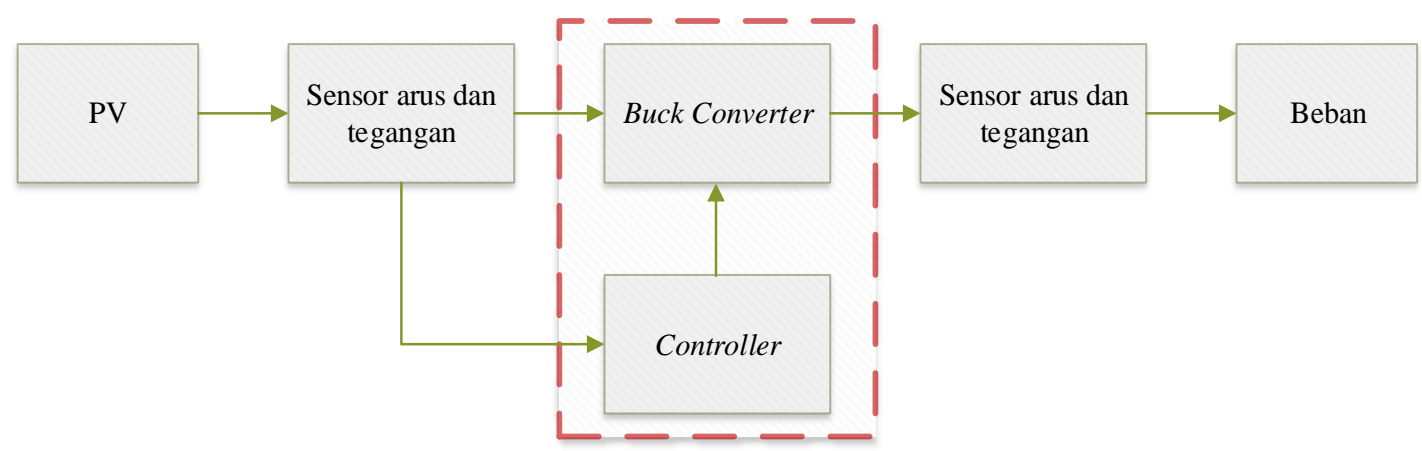

Gambar 1. Diagram Blok Secara Umum Sistem PV Menggunakan Non-Synchronous Buck Converter 


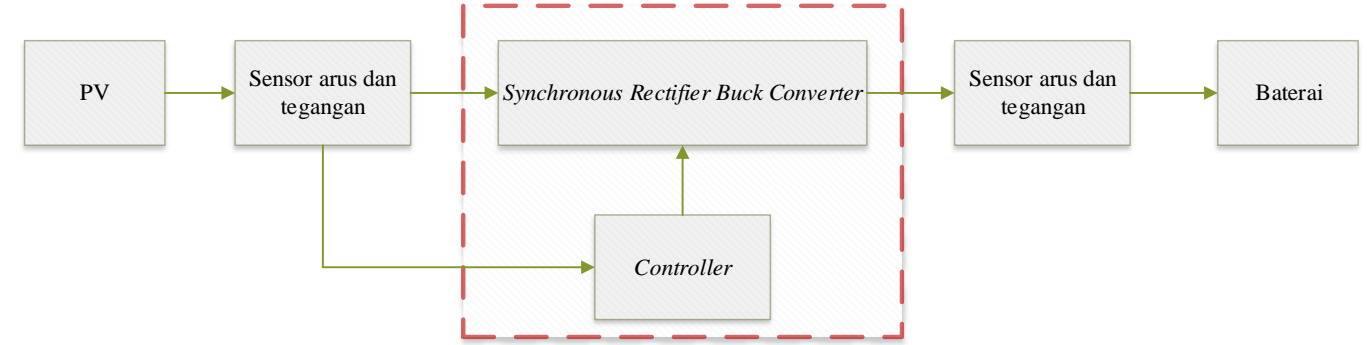

Gambar 2. Diagram Blok Desain Sistem PV Menggunakan Synchronous Buck Converter

\subsection{Perancangan PV}

Nilai parameter PV yang dipakai pada simulasi ini ialah tipe KC200GT-200W. Secara garis besar pemodelan PV ini didapatkan dari persamaan yang telah disesuaikan dengan karakteristik PV itu sendiri pada umumnya. Gambar 3 menunjukkan rangkaian umum PV secara skematik.

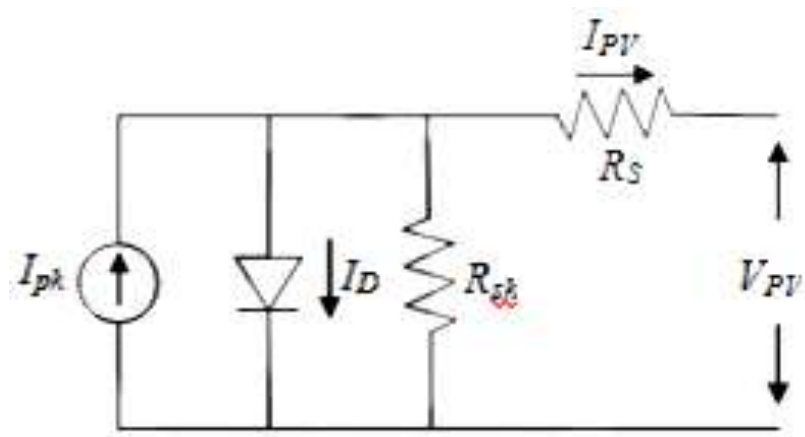

Gambar 3. Rangkaian Umum PV Secara Skematik

Tabel 1 menunjukkan parameter PV yang akan digunakan dalam pemodelan PV secara matematis.

Tabel 1. Parameter PV

\begin{tabular}{lll}
\hline Characteristic & Unit & KC200GT-200W \\
\hline Maximum power (Pmax) & W & 200.143 \\
\hline Maximum Power Voltage (Vmp) & V & 26.3 \\
\hline Maximum Power Current (Imp) & A & 7.61 \\
\hline Short Circuit Current (Isc) & A & 8.21 \\
\hline Open Circuit Voltage (Voc) & V & 32.9 \\
\hline
\end{tabular}

Persamaan 1, Persamaan 2, Persamaan 3, Persamaan 4 didapat dari pemodelan dibuat secara bertahap sesuai dengan Persamaan nilai yang sudah ditentukan.

$$
\begin{aligned}
& I_{p h}=\left(I_{s c}+K_{I}\left(T_{k}-T_{r e f}\right)\right) \frac{G}{G_{r e f}} \\
& I_{r s}=\frac{I_{s c}}{\left[\exp \left(\frac{q V_{o c}}{N_{S} K A T}\right)-1\right]} \\
& I_{s}=I_{r s}\left[\frac{T}{T_{r e f}}\right] \exp \left[\frac{q E_{g}}{A k}\left(\frac{1}{T_{r e f}}-\frac{1}{T}\right)\right] \\
& I_{p v}=N_{p} I_{p h}-N_{p} I_{o}\left[\exp \left(\frac{q V_{o c}}{N_{S} K A T}\right)-1\right]
\end{aligned}
$$

Gambar 4 menunjukkan rangkaian PV secara matematis dengan perancangan PV yang dirancang secara matematis dengan menghasilkan PV murni 200 Watt dan ditingkatkan daya sehingga mencapai 1200 watt.

Studi Analisa Synchronous Rectifier Buck Converter..., Ari Robiul Ichsan, Machmud Effendy, 


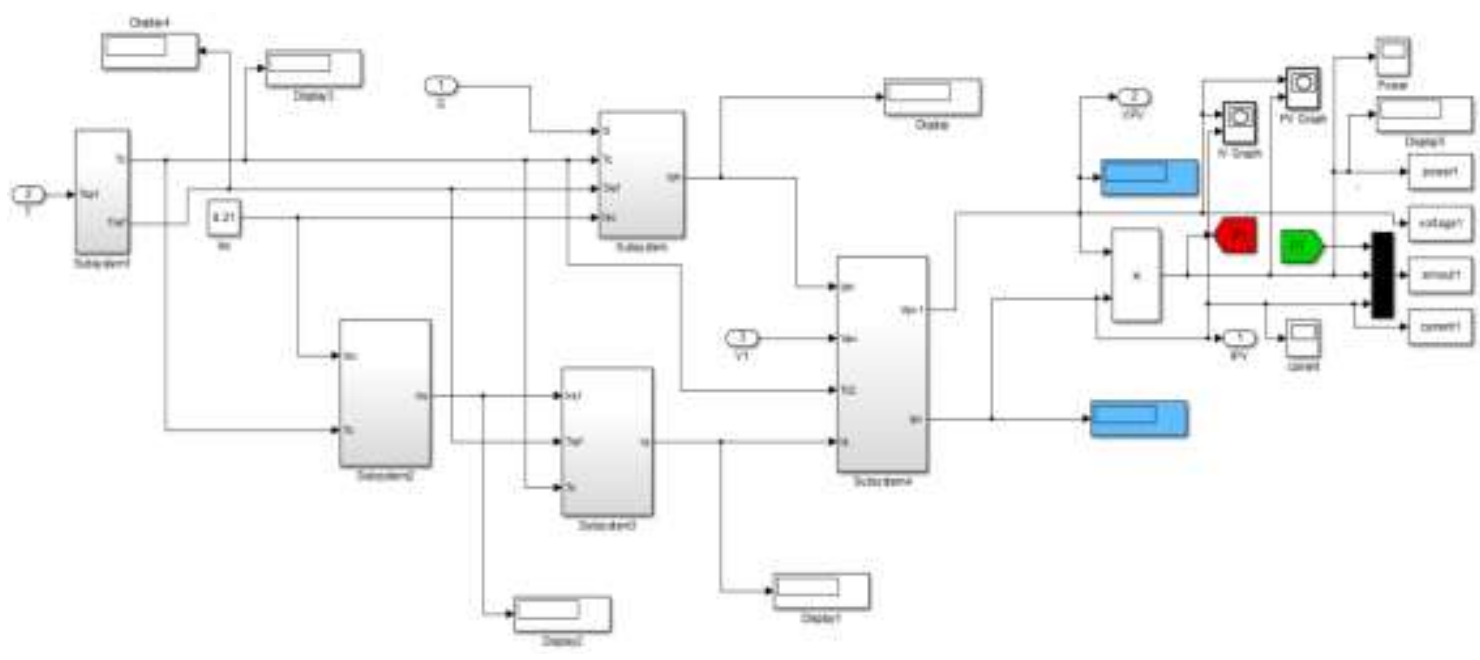

Gambar 4. Rangkaian PV Secara Matematis

\subsection{Perancangan Converter DC Sebagai Penurun Tegangan PV}

Converter DC yang digunakan ialah buck converter mengubah nilai tegangan masuk dari sumber PV sebesar $32.9 \mathrm{~V}$ ke nilai tegangan keluaran yang lebih rendah sebesar $12 \mathrm{~V}$ dengan frekuensi switching $10 \mathrm{kHz}$. Tabel 2 Parameter nilai untuk perancangan konverter DC dan Gambar 5 rangkaian simulasi buck converter dengan penyearah sisi bawah menggunakan dioda yang sudah dirancang.

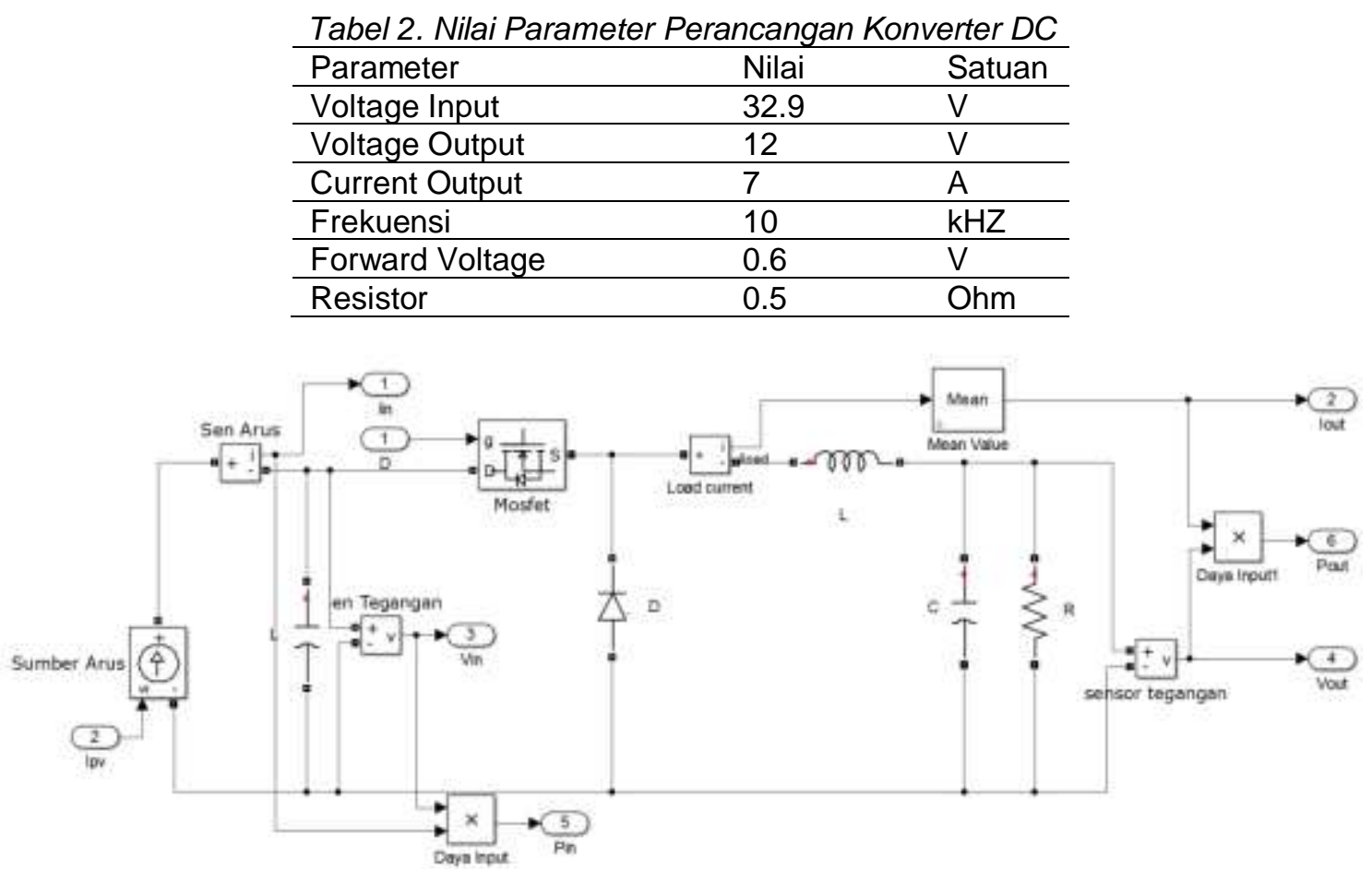

Gambar 5. Rangkaian Umum Buck Converter Dengan Sumber PV

Perhitungan untuk merancang konverter DC tipe penurun tegangan menggunakan Persamaan 5, Persamaan 6, Persamaan 7, Persamaan 8, Persamaan 9, Persamaan 10. Dari Persamaan tersebut, maka dapat dihasilkan nilai dari setiap komponen ditunjukkan Tabel 3.

$$
D=\frac{V_{\text {Out }}}{V_{\text {In }}}
$$

KINETIK Vol. 2, No. 3, Agustus 2017: 151-164 


$$
\begin{array}{ll}
\mathrm{IL} & =\frac{V_{o}}{R}=I_{O} \\
\Delta \mathrm{LL} & =0.3 \times \mathrm{L} \\
\mathrm{L} & =\left(\frac{1}{f}\right) \cdot\left(V_{\text {in }}-V_{\text {out }}\right) \cdot\left(\frac{V_{\text {out }}+V_{f}}{V_{\text {in }}+V_{f}}\right) \cdot\left(\frac{1}{\Delta I L}\right) \\
\Delta \mathrm{V}_{\mathrm{o}} & = \pm 0.1 \%+\text { Vout } \\
& \mathrm{C} \quad=\frac{\Delta_{\text {IL }}}{8 . f . \Delta V_{o}}
\end{array}
$$

Tabel 3. Hasil Persamaan 5 Sampai Dengan Persamaan 10

\begin{tabular}{lll}
\hline Komponen & Nilai & Satuan \\
\hline Duty cycle & 0.40 & $\%$ \\
\hline Induktor & 0.00037 & henry \\
\hline Kapasitor & 0.0022 & farad \\
\hline
\end{tabular}

Sebagai pembandingnya Gambar 6 menunjukkan simulasi rangkaian synchronous buck converter menggunakan sumber PV sebagai perbandingan dengan hasil luaran efisiensi daya non-synchronous buck converter.

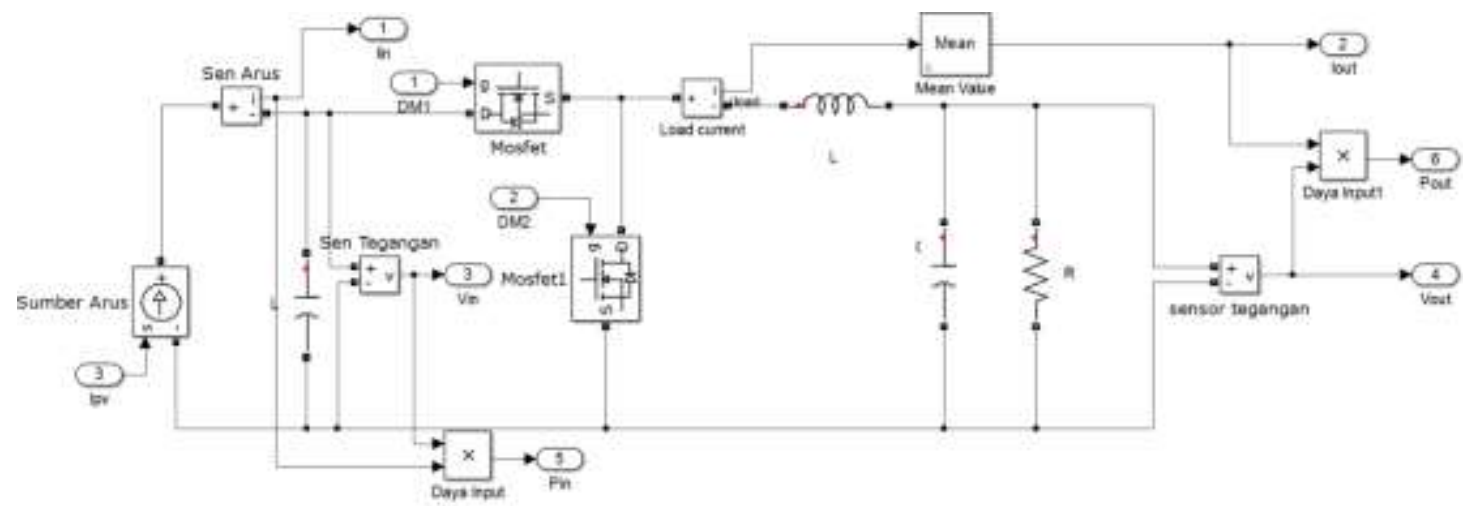

Gambar 6. Rangkaian Synchronous Buck Converter Dengan Sumber PV

Pada analisa ini akan membandingkan hasil efisiensi daya sistem PV menggunakan nonsynchronous buck converter lalu dibandingkan dengan synchronous buck converter. Efisiensi daya secara umum dapat dihitung dengan Persamaan 11.

$$
\eta=\frac{P_{\text {OUT }}}{P_{I N}}
$$

Frekuensi switching yang dipakai mulai $10 \mathrm{kHz}, 20 \mathrm{kHz}$ sampai $30 \mathrm{kHz}$. Duty cycle yang dipakai mulai dari $40 \%, 50 \%, 60 \%, 70 \%, 80 \%$ sampai $90 \%$. Ini bertujuan untuk menganalisis pengaruh hasil keluaran jika nilai frekuensi dan duty cycle dinaikkan.

\subsection{Perancangan Converter DC Sebagai Penurun Tegangan PV Menggunakan Beban Baterai}

Pada perancangan ini, sistem PV yang awalnya menggunakan beban resistor bernilai $0.5 \mathrm{Ohm}$ kini diganti dengan menggunakan baterai lead-acid $12 \mathrm{~V}$ dan $140 \mathrm{AH}$. Gambar 7 ialah rangkaian sistem PV dari sumber PV menggunakan non-synchronous buck converter dengan beban baterai. Sebagai pembanding Gambar 8 adalah rangkaian sistem PV dari sumber PV menggunakan synchronous buck converter dengan beban baterai.

Pada analisa ini akan membandingkan sistem PV menggunakan non-synchronous buck converter dengan synchronous buck converter yang akan dialirkan ke beban baterai lead-acid.

Studi Analisa Synchronous Rectifier Buck Converter..., Ari Robiul Ichsan, Machmud Effendy, 
Tabel 2 konverter DC tipe penurun yang akan dipakai menggunakan nilai parameter yang sudah ditentukan dan dihitung sebelumnya ialah frekuensi $10 \mathrm{kHz}$ dan duty cycle $40 \%$.

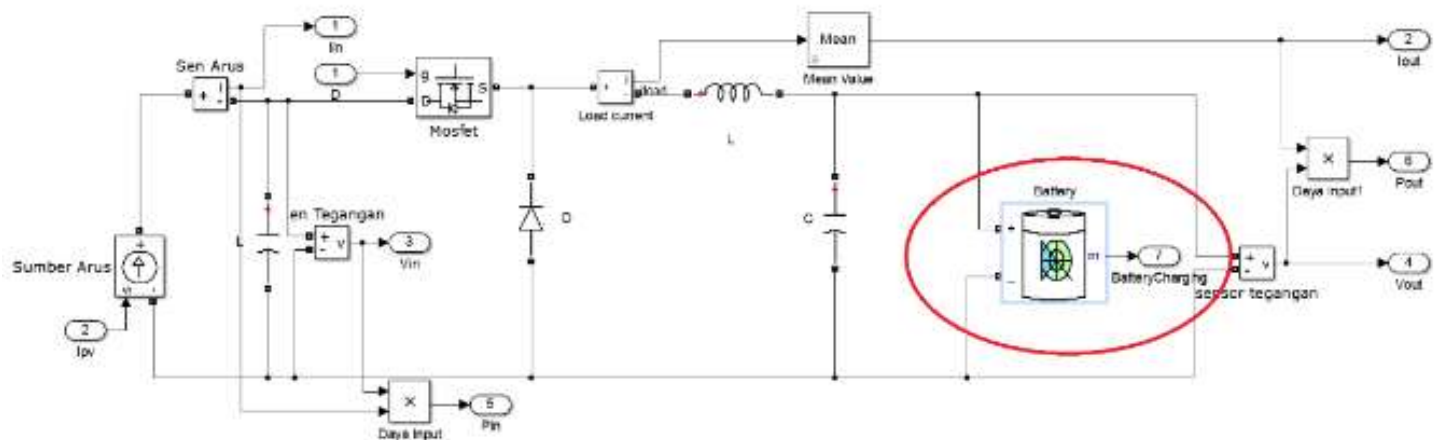

Gambar 7. Rangkaian Non-Synchronous Buck Converter Dengan Beban Baterai Lead-acid

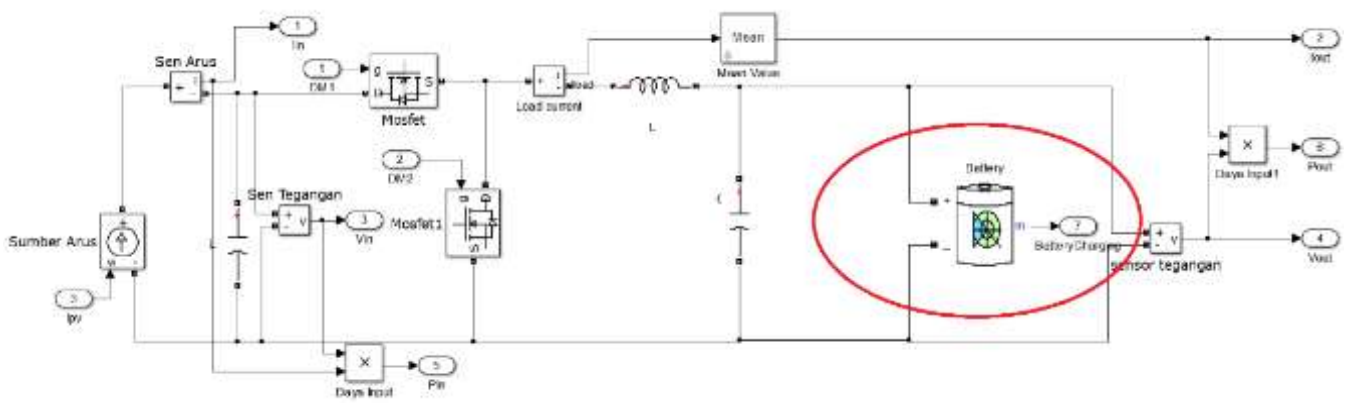

Gambar 8. Rangkaian Synchronous Buck Converter Dengan Beban Baterai Lead-acid

\section{Hasil Penelitian dan Pembahasan}

\subsection{Hasil Simulasi PV}

Gambar 9 menunjukkan hasil PV murni persamaan tegangan dan arus dengan daya 200 watt, sedangkan Gambar 10 menampilkan PV murni persamaan daya dan tegangan. Dalam Gambar 10 (a) adalah persamaan arus dan tegangan dengan daya yang sudah ditingkatkan sebesar 1200 watt, sedangkan Gambar 10 (b) merupakan persamaan daya dan tegangan yang sudah ditingkatkan sebesar 1200 watt.

\subsection{Hasil Simulasi Sistem PV}

\subsubsection{Hasil Simulasi Sistem PV dengan Non-Synchronous Buck Converter}

Dalam bab ini menggunakan duty cycle sesuai dengan persamaan (5) ialah $40 \%$. Gambar 11 menunjukkan hasil simulasi sistem PV dengan non-synchronous buck converter pada frekuensi $10 \mathrm{kHZ}$ sedangkan Gambar 12 menunjukkan hasil simulasi sistem PV dengan nonsynchronous buck converter pada frekuensi $20 \mathrm{kHz}$ dan Gambar 13 menunjukkan hasil simulasi sistem PV dengan non-synchronous buck converter pada frekuensi $30 \mathrm{kHz}$.

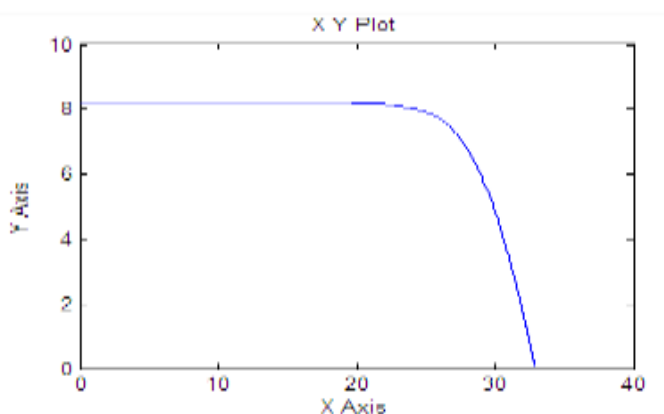

(a)

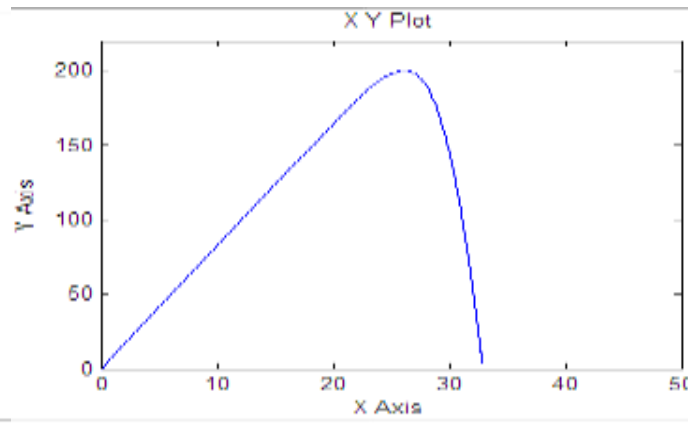

(b)

Gambar 9. (a) Persamaan Arus dan Tegangan (b) Persamaan Antara Daya dan Tegangan

KINETIK Vol. 2, No. 3, Agustus 2017: 151-164 


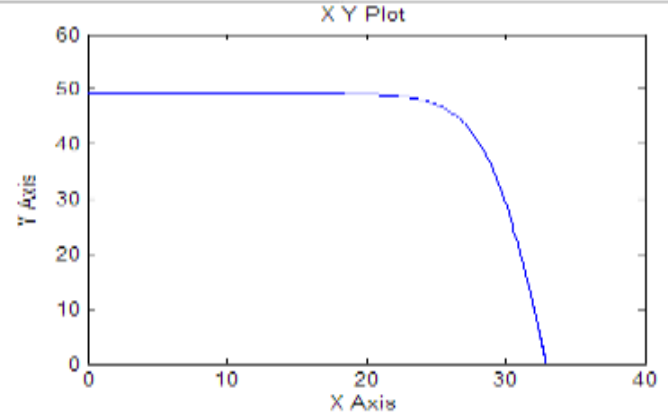

(a)

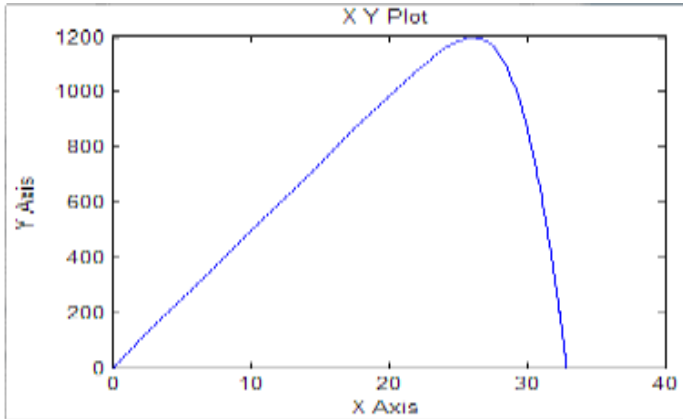

(b)

Gambar 10. (a) Persamaan Arus dan Tegangan (b) Persamaan Daya dan Tegangan

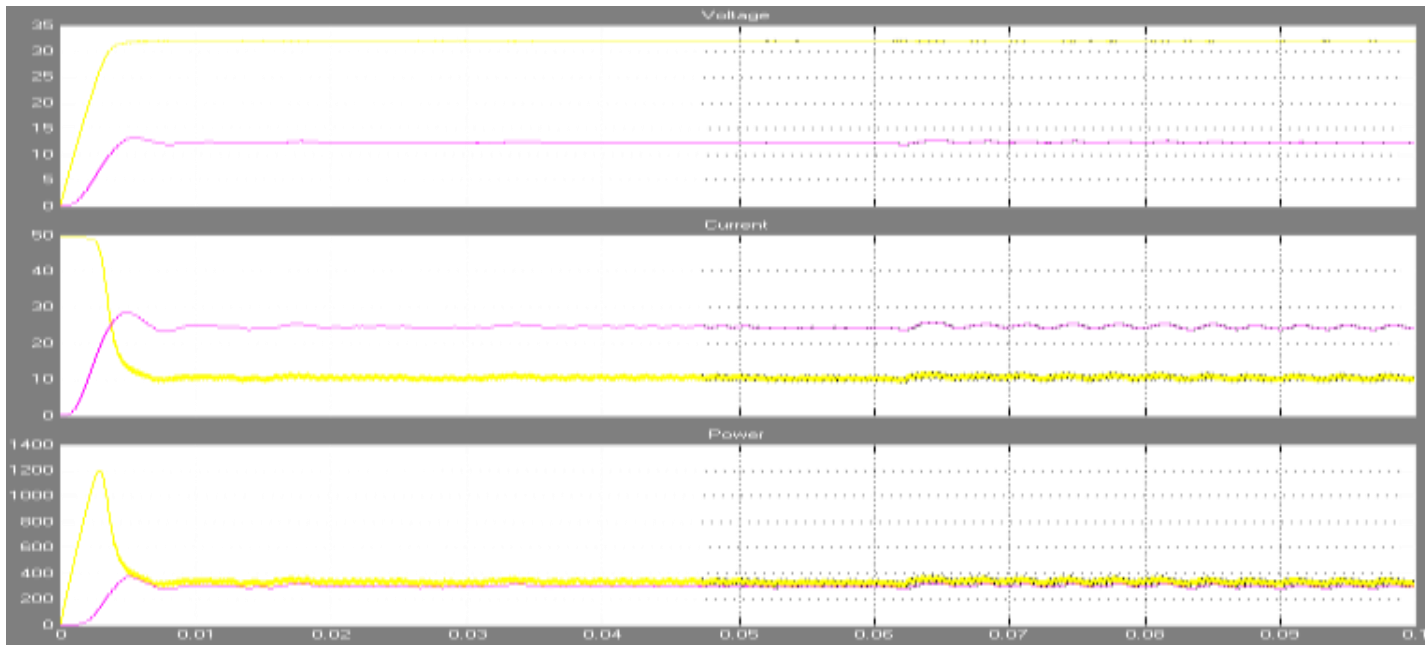

Gambar 11. Hasil Grafik Frekuensi $10 \mathrm{kHz}$

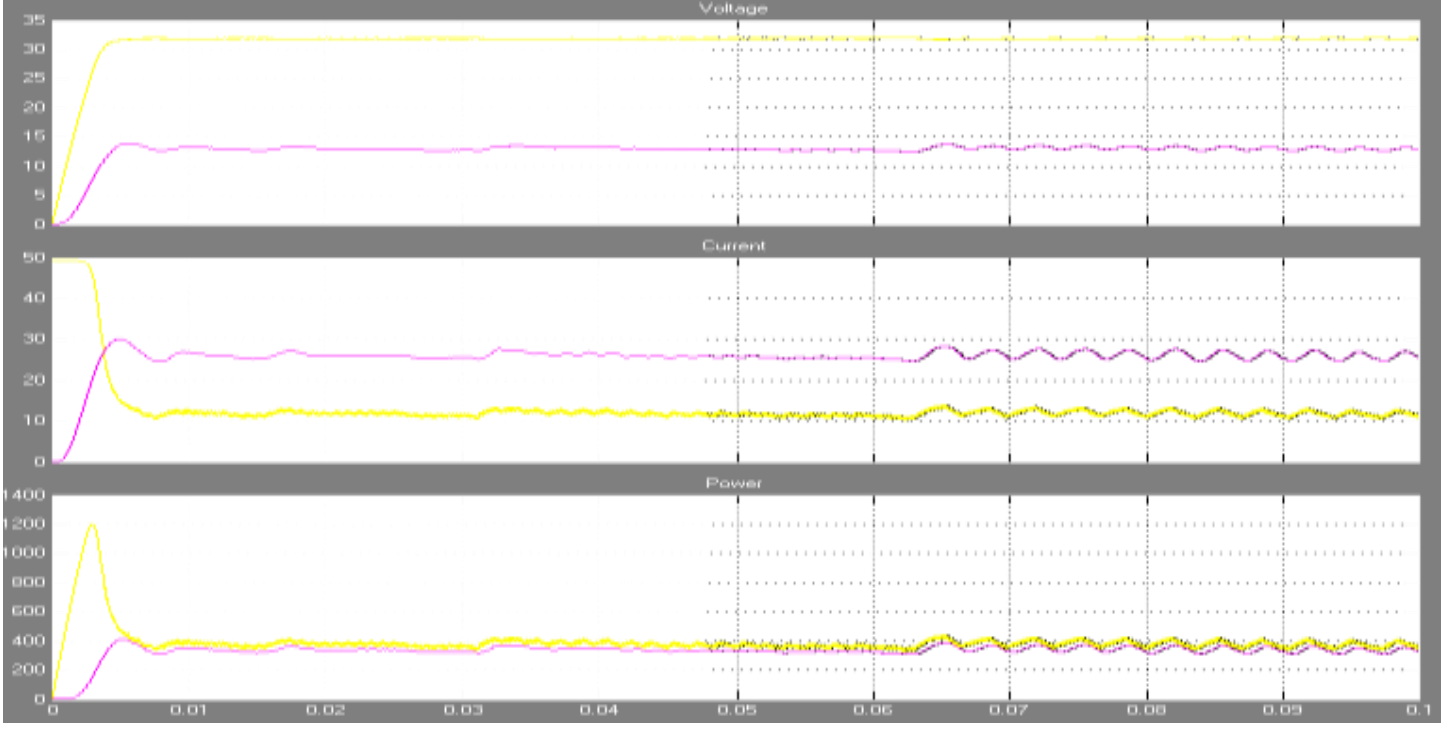

Gambar 12. Hasil Grafik Frekuensi $20 \mathrm{KHz}$ 


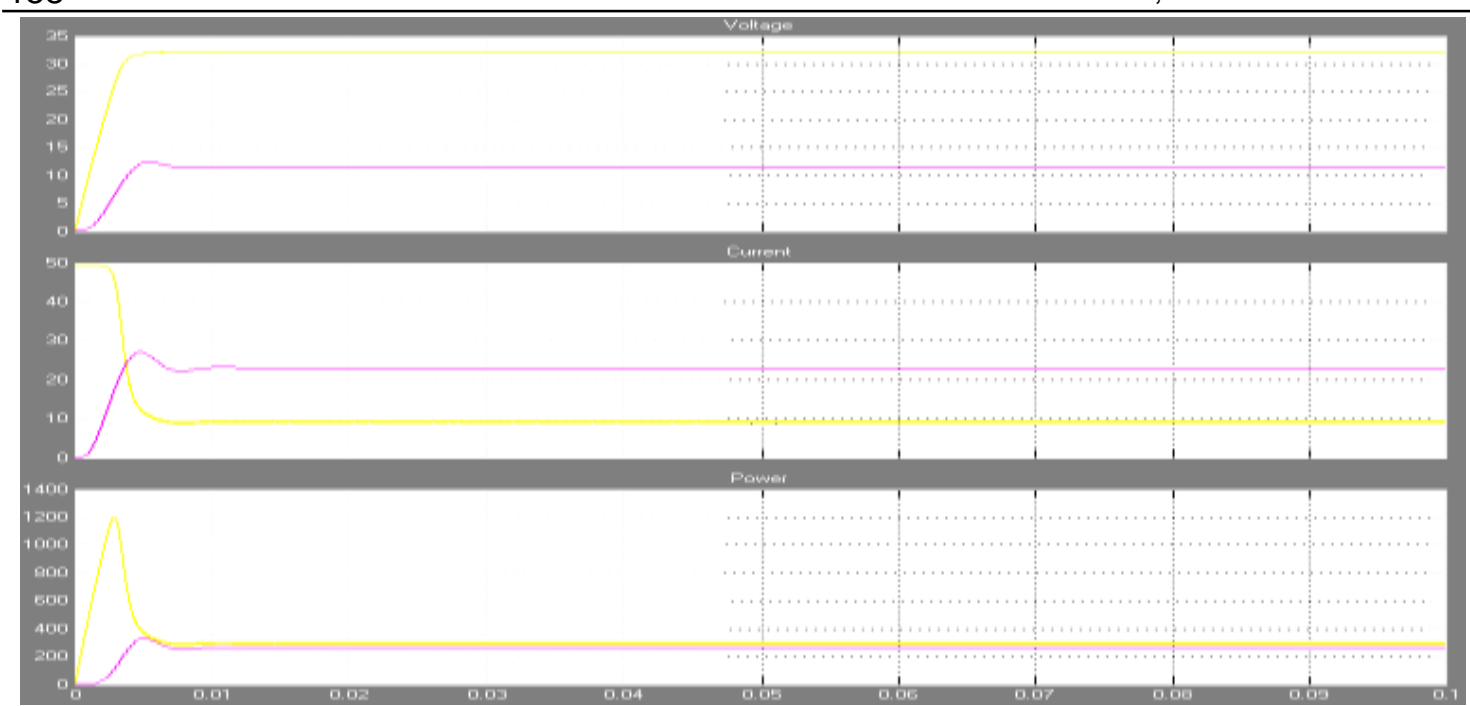

Gambar 13. Hasil Grafik Frekuensi 30 kHz

Tabel 4. Hasil Simulasi Sistem PV Dengan Non-Synchronous Buck

\begin{tabular}{|c|c|c|c|c|c|c|c|c|}
\hline \multirow{2}{*}{$\begin{array}{c}\mathrm{F} \\
(\mathrm{kHz})\end{array}$} & \multirow{2}{*}{$\begin{array}{l}D \\
(\%)\end{array}$} & \multicolumn{2}{|c|}{ Source (V) } & \multicolumn{2}{|c|}{ Current (A) } & \multicolumn{2}{|c|}{ Power (Watt) } & \multirow{2}{*}{$\begin{array}{c}\text { Power } \\
\text { Efficiency (n) }\end{array}$} \\
\hline & & Input & Output & Input & Output & Input & Output & \\
\hline \multirow{6}{*}{10} & 40 & 32.1 & 12.13 & 9.382 & 24.03 & 301.1 & 291.5 & 96.81 \\
\hline & 50 & 31.59 & 14.86 & 14.82 & 29.86 & 468.1 & 443.8 & 94.83 \\
\hline & 60 & 30.97 & 16.91 & 20.94 & 33.65 & 648.5 & 568.9 & 87.71 \\
\hline & 70 & 30.26 & 18.96 & 27.13 & 37.75 & 820.9 & 715.8 & 87.19 \\
\hline & 80 & 29.25 & 20.76 & 34.32 & 41.73 & 1004 & 866.2 & 86.28 \\
\hline & 90 & 28.13 & 21.76 & 40.16 & 43.32 & 1130 & 942.6 & 83.44 \\
\hline \multirow{6}{*}{20} & 40 & 31.92 & 12.94 & 11.29 & 25.65 & 360.4 & 332 & 92.11 \\
\hline & 50 & 31.12 & 16.43 & 19.53 & 32.87 & 607.8 & 540.2 & 88.87 \\
\hline & 60 & 30.67 & 17.78 & 23.63 & 36.07 & 724.8 & 641.3 & 88.48 \\
\hline & 70 & 29.54 & 20.26 & 34.42 & 40.43 & 957.9 & 821.3 & 85.74 \\
\hline & 80 & 29.17 & 20.8 & 34.81 & 41.21 & 1015 & 857.4 & 84.44 \\
\hline & 90 & 26.77 & 22.31 & 44.62 & 44.62 & 1195 & 995.6 & 83.33 \\
\hline \multirow{6}{*}{30} & 40 & 32.13 & 11.55 & 9.033 & 23.09 & 290.2 & 266.6 & 91.88 \\
\hline & 50 & 31.66 & 14.1 & 14.11 & 28.21 & 446.6 & 397.9 & 89.09 \\
\hline & 60 & 31.09 & 16.43 & 19.78 & 32.87 & 615.1 & 540.1 & 87.81 \\
\hline & 70 & 30.41 & 18.5 & 25.84 & 37.01 & 786 & 684.8 & 87.12 \\
\hline & 80 & 29.55 & 20.26 & 32.37 & 40.53 & 956.5 & 821.2 & 85.85 \\
\hline & 90 & 28.4 & 21.61 & 38.95 & 43.23 & 11.06 & 934.3 & 84.47 \\
\hline
\end{tabular}

\subsubsection{Hasil Simulasi Sistem PV Dengan Synchronous Buck Converter}

Dalam bab ini menggunakan nilai duty cycle sesuai dengan persamaan (5) ialah $40 \%$. Gambar 14 menunjukkan hasil simulasi sistem PV dengan synchronous buck converter pada frekuensi $10 \mathrm{kHZ}$ sedangkan Gambar 15 menunjukkan hasil simulasi sistem PV dengan synchronous buck converter pada frekuensi $20 \mathrm{kHz}$ dan Gambar 16 menunjukkan hasil simulasi sistem PV dengan synchronous buck converter pada frekuensi $30 \mathrm{kHz}$. 


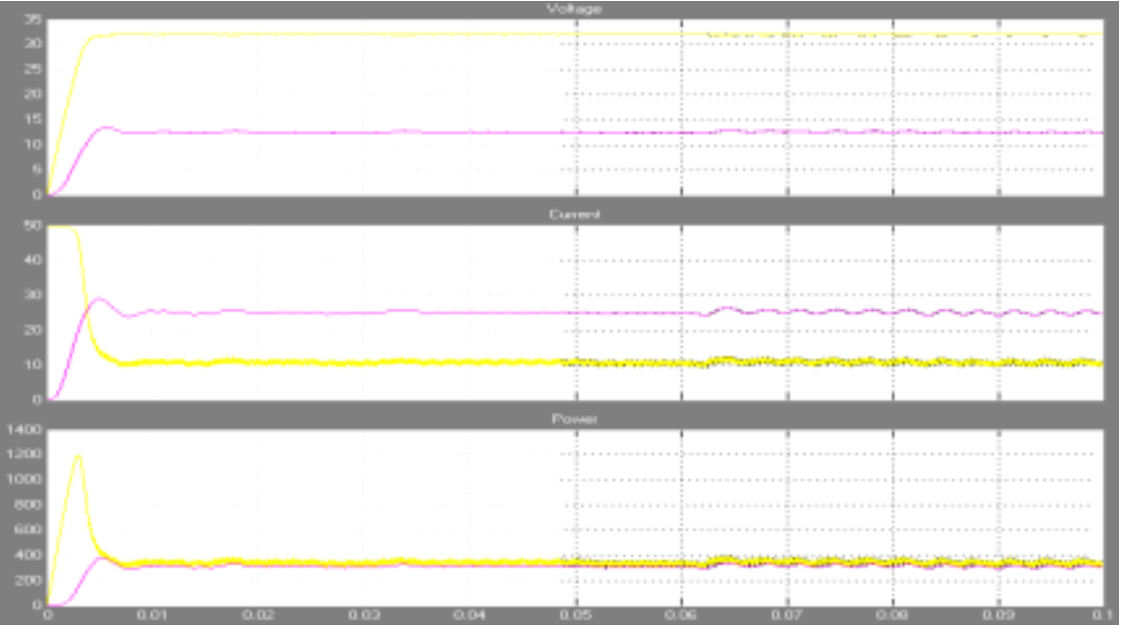

Gambar 14. Hasil Grafik Dengan Frekuensi $10 \mathrm{kHz}$

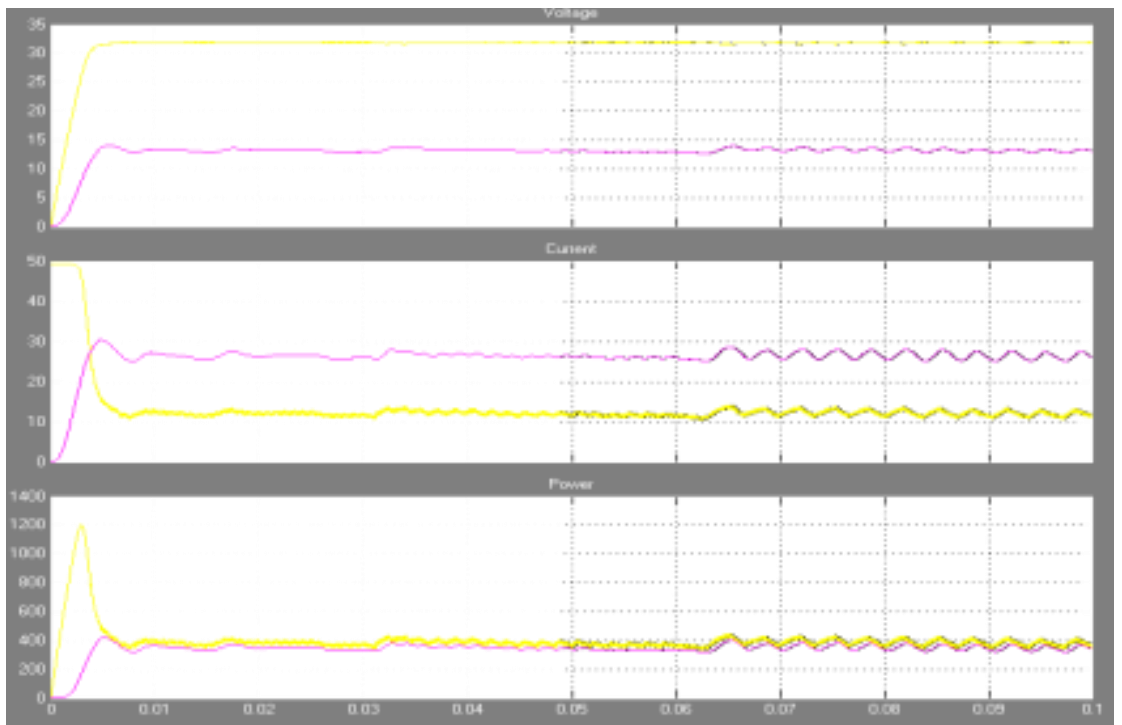

Gambar 15. Hasil Grafik Dengan Frekuensi 20 kHz

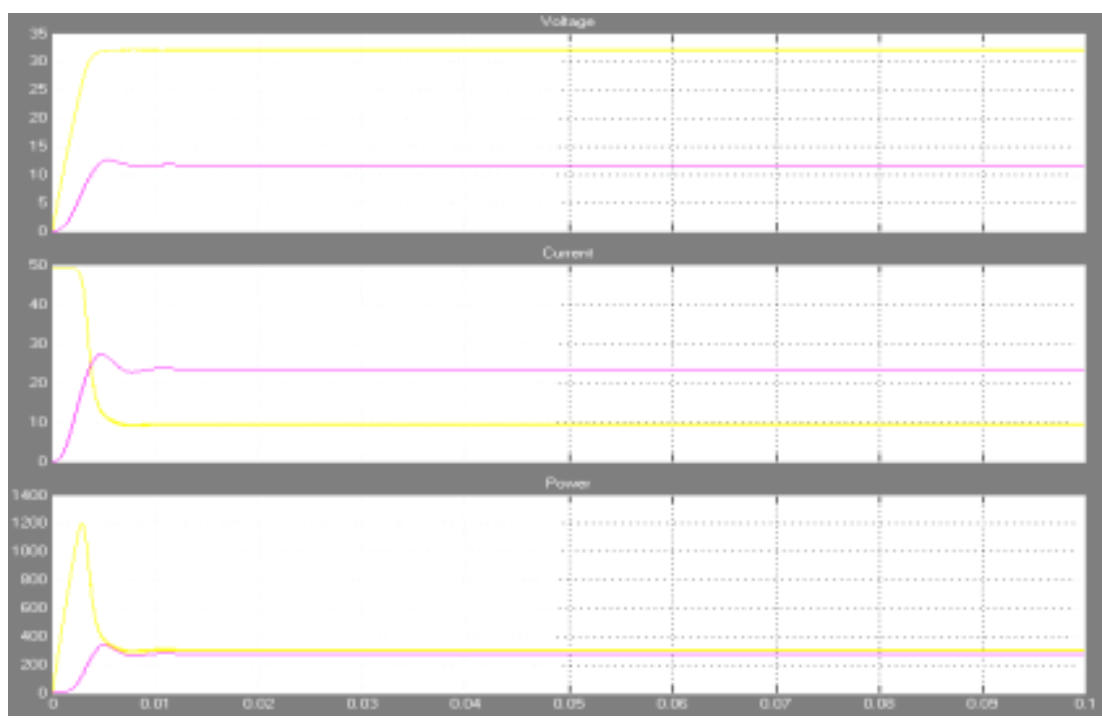

Gambar 16. Hasil Grafik Dengan Frekuensi 30 kHz 
Tabel 5 menunjukkan hasil simulasi sistem PV dengan synchronous buck converter menggunakan duty cycle mulai dari $40 \%, 50 \%, 60 \%, 70 \%, 80 \%$ sampai $90 \%$ dengan frekuensi yang digunakan ialah 10,20 , dan $30 \mathrm{kHz}$.

Tabel 5. Hasil Simulasi Sistem PV Dengan Synchronous Buck Converter

\begin{tabular}{ccccccccc}
\hline $\mathrm{F}$ & $\mathrm{D}$ & \multicolumn{2}{c}{ Source $(\mathrm{V})$} & \multicolumn{2}{c}{ Current $(\mathrm{A})$} & \multicolumn{2}{c}{ Power (Watt) } & Power \\
$(\mathrm{kHz})$ & $(\%)$ & Input & Output & Input & Output & Input & Output & Efficiency $(\mathrm{\eta})$ \\
\hline \multirow{6}{*}{10} & 40 & 32.1 & 12.34 & 9.545 & 24.45 & 306.2 & 301.6 & 98.47 \\
& 50 & 31.6 & 15.01 & 14.96 & 30.15 & 472.4 & 452.4 & 95.76 \\
& 60 & 31 & 17.01 & 21.07 & 33.86 & 652.2 & 575.8 & 88.29 \\
& 70 & 30.3 & 19.02 & 27.22 & 37.88 & 823.4 & 720.5 & 87.51 \\
& 80 & 29.2 & 20.79 & 34.37 & 41.79 & 1005 & 868.9 & 86.44 \\
& 90 & 28.1 & 21.77 & 40.18 & 43.35 & 1130 & 943.8 & 83.51 \\
\hline \multirow{4}{*}{20} & 40 & 31.9 & 13.13 & 11.46 & 26.02 & 365.5 & 341.6 & 93.44 \\
& 50 & 31.1 & 16.55 & 19.67 & 33.09 & 611.7 & 547.5 & 89.51 \\
& 60 & 30.7 & 17.87 & 23.74 & 36.24 & 727.9 & 647.4 & 88.95 \\
& 70 & 29.5 & 20.3 & 32.49 & 40.61 & 959.5 & 924.5 & 85.94 \\
& 80 & 2916 & 20.83 & 34.86 & 41.28 & 1017 & 859.9 & 84.59 \\
& 90 & 26.8 & 22.31 & 44.62 & 44.62 & 1195 & 995.6 & 83.33 \\
\hline \multirow{6}{*}{30} & 40 & 32.1 & 11.77 & 9.206 & 23.54 & 295.6 & 277 & 93.68 \\
& 50 & 31.6 & 14.26 & 14.27 & 28.53 & 451.5 & 407 & 90.14 \\
& 60 & 31.1 & 16.54 & 19.92 & 33.09 & 619 & 547.5 & 88.44 \\
& 70 & 30.4 & 18.57 & 25.94 & 37.18 & 788.8 & 690.1 & 87.49 \\
& 80 & 29.5 & 20.3 & 32.43 & 40.61 & 958.1 & 824.4 & 86.05 \\
& 90 & 28.4 & 21.63 & 38.98 & 43.26 & 1107 & 935.7 & 84.55 \\
\hline
\end{tabular}

\subsection{Hasil Perbandingan Efisiensi Daya Sistem PV}

Pada bab ini menjelaskan hasil perbandingan efisiensi daya dari sistem PV dengan konverter DC tipe penurun tegangan memakai MOSFET sinkronisasi lalu dibandingkan dengan MOSFET tanpa sinkronisasi. Gambar 17 ialah grafik analisa perbandingan efisiensi daya memakai frekuensi yang sudah ditetapkan pada penentuan nilai parameter sebelumnya, yaitu Tabel 2 sebesar $10 \mathrm{kHz}$ dengan duty cycle mulai dari 40\%,50\%, 60\%, 70\%, 80\% sampai $90 \%$.

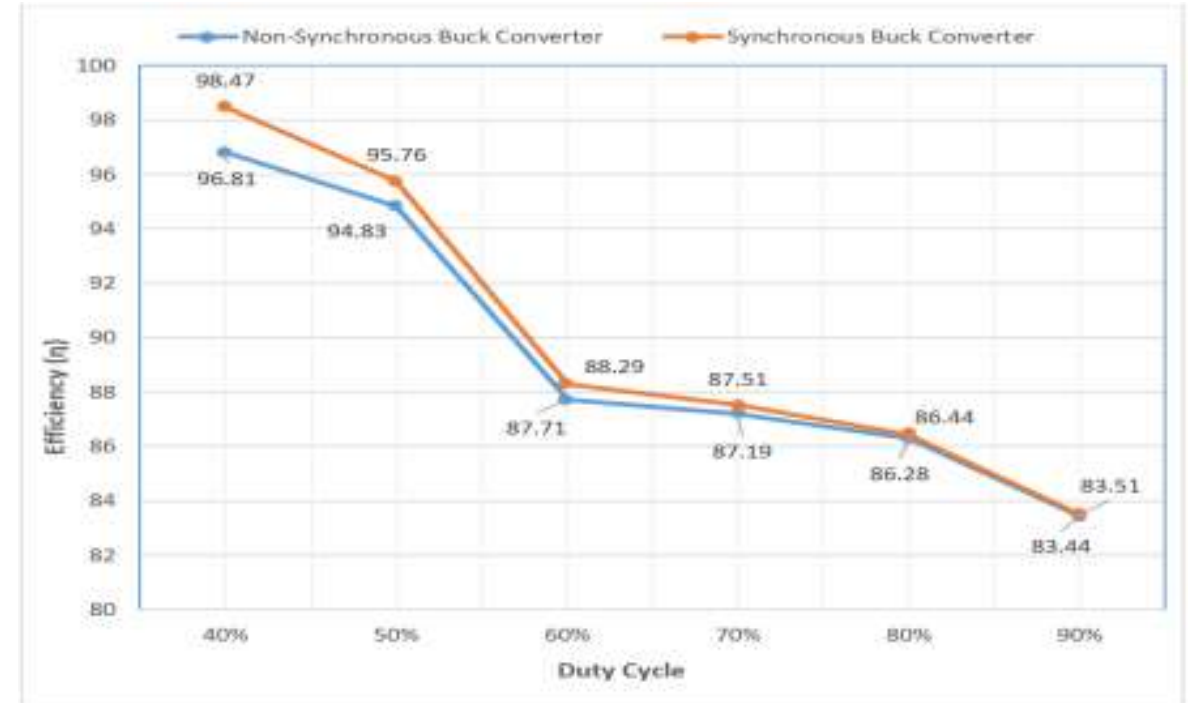

Gambar 17. Grafik Perbandingan Efisiensi Daya Pada Sistem PV 
Jadi, peneliti bisa menyimpulkan bahwa pada sistem PV dengan menggunakan converter DC tipe penurun tegangan atau yang disebut buck converter efisiensi yang dihasilkan lebih rendah dibandingkan dengan synchronous buck converter. Selisih efisiensi daya dari kedua converter DC tipe penurun tersebut pada duty cycle $40 \%$ ialah $1.66 \%$ tepat di frekuensi $10 \mathrm{kHz}$, perbedaan efisiensi daya tersebut ialah perbedaan yang paling jauh di frekuensi $10 \mathrm{kHz}$. Jadi semakin tinggi nilai duty cycle maka keluaran tegangan, arus dan daya akan semakin tinggi, tetapi pada efisiensi daya yang dihasilkan dari kedua converter DC tipe penurun tegangan tersebut akan semakin rendah, keduanya hampir menghasilkan nilai yang sama ketika nilai duty cycle semakin dinaikkan.

\section{Hasil Simulasi Sistem PV dengan Beban Baterai}

Pada hasil simulasi sistem PV ini, kedua converter DC tipe penurun tegangan tersebut akan menggunakan beban baterai lead-acid $12 \mathrm{~V}$ memakai frekuensi yang sudah ditetapkan dalam Tabel 2 ialah $10 \mathrm{kHz}$ dan nilai duty cycle sesuai dengan hasil persamaan (5), yaitu $40 \%$. Gambar 18 adalah hasil grafik keluaran tegangan, arus dan daya pada sistem PV menggunakan non-synchronous buck converter dan Gambar 19 adalah hasil grafik keluaran tegangan, arus dan daya pada sistem PV menggunakan synchronous buck converter.

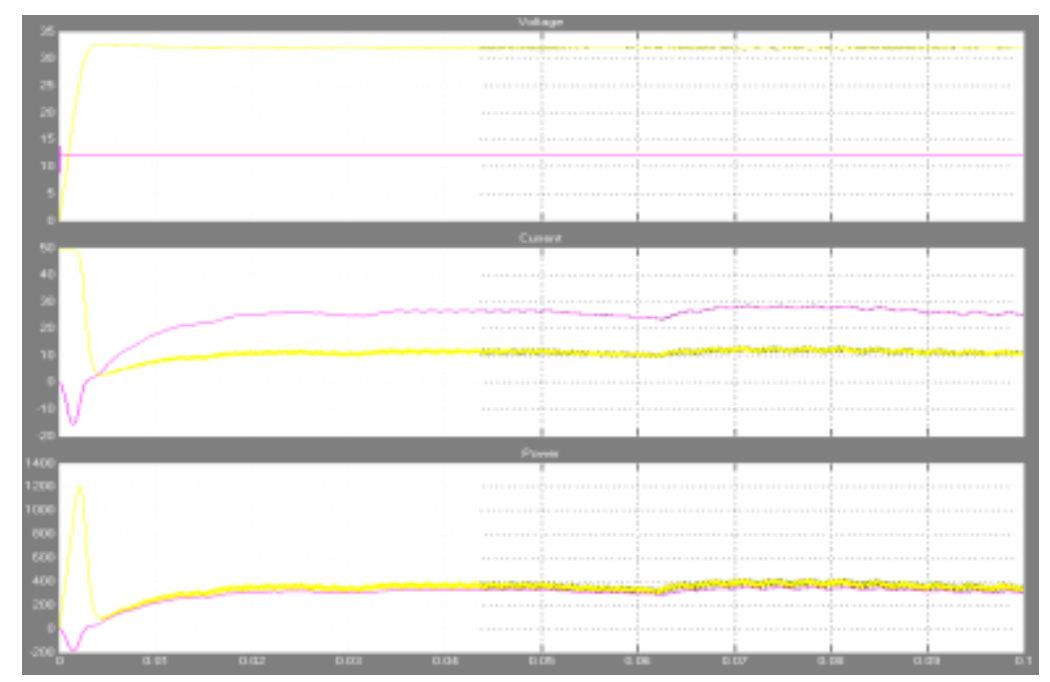

Gambar 18. Hasil Grafik Keluaran Non-Synchronous Buck Converter Dengan Beban Baterai

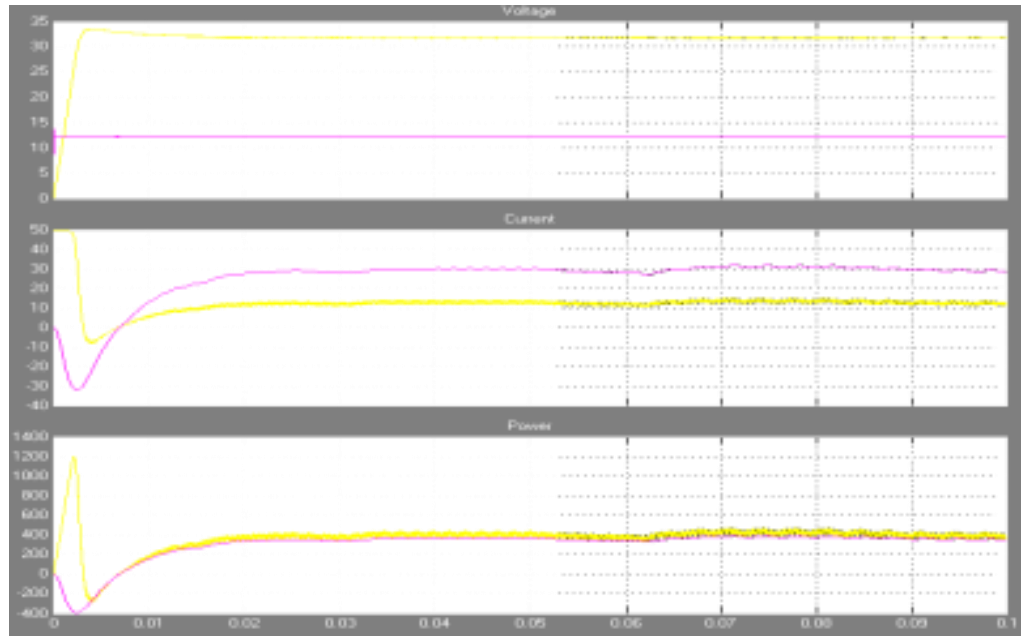

Gambar 19. Hasil Grafik Keluaran Synchronous Buck Converter Dengan Beban Baterai

Tabel 6 menunjukkan hasil simulasi sistem PV dengan non-synchronous buck converter dan synchronous buck converter menggunakan beban baterai, duty cycle yang dipakai mulai dari 
$40 \%, 50 \%, 60 \%, 70 \%, 80 \%$, sampai $90 \%$ dengan frekuensi yang sudah ditetapkan pada Tabel 2 ialah $10 \mathrm{kHz}$.

Tabel 6. Hasil Sistem PV Dengan Menggunakan Beban Baterai

\begin{tabular}{|c|c|c|c|c|c|c|c|c|}
\hline \multirow[b]{2}{*}{ Konverter DC } & \multirow[b]{2}{*}{$\begin{array}{c}D \\
(\%)\end{array}$} & \multicolumn{2}{|c|}{ Source (V) } & \multicolumn{2}{|c|}{ Current $(\mathrm{A})$} & \multicolumn{2}{|c|}{ Power (Watt) } & \multirow{2}{*}{$\begin{array}{c}\text { Power } \\
\text { Efficiency } \\
(\eta)\end{array}$} \\
\hline & & Input & Output & Input & Output & Input & Output & \\
\hline \multirow{6}{*}{$\begin{array}{c}\text { Non- } \\
\text { synchronous } \\
\text { Buck } \\
\text { Converter }\end{array}$} & 40 & 32.06 & 12.21 & 9.778 & 25.06 & 313.5 & 305.9 & 97.58 \\
\hline & 50 & 29.88 & 12.24 & 30.04 & 59.34 & 897.7 & 726.3 & 80.91 \\
\hline & 60 & 27.09 & 12.25 & 43.81 & 70.11 & 11.87 & 858.9 & 72.38 \\
\hline & 70 & 23.87 & 12.25 & 48.33 & 66.6 & 1154 & 815.7 & 70.71 \\
\hline & 80 & 20.9 & 12.24 & 49.09 & 59.63 & 1026 & 730 & 71.14 \\
\hline & 90 & 18.65 & 12.23 & 49.22 & 53.02 & 917.7 & 648.6 & 70.68 \\
\hline \multirow{6}{*}{$\begin{array}{c}\text { Synchronous } \\
\text { Buck } \\
\text { Converter }\end{array}$} & 40 & 31.94 & 12.21 & 11.13 & 28.48 & 355.5 & 347.7 & 97.82 \\
\hline & 50 & 29.84 & 12.24 & 30.35 & 59.92 & 905.7 & 733.4 & 80.91 \\
\hline & 60 & 27.09 & 12.25 & 43.85 & 70.16 & 1187 & 859.6 & 72.41 \\
\hline & 70 & 23.85 & 12.25 & 48.34 & 66.61 & 1153 & 815.8 & 70.77 \\
\hline & 80 & 20.88 & 12.24 & 49.1 & 59.63 & 1025 & 730 & 71.22 \\
\hline & 90 & 18.63 & 12.23 & 49.22 & 53.02 & 917 & 648.6 & 70.73 \\
\hline
\end{tabular}

\section{Kesimpulan}

Pengaplikasian sistem PV dengan kedua converter DC-DC tipe buck adalah semakin tinggi nilai duty cycle maka akan semakin tinggi nilai keluaran tegangan dan arus pada sistem PV, tetapi pada efisiensi daya yang dihasilkan akan menurun itu disebabkan perancangan nilai duty cycle yang sudah dihitung sebelumnya tidak sesuai dengan nilai parameter tegangan keluaran yang diinginkan yaitu sebesar $12 \mathrm{~V}$ sesuai dengan Persamaan (5).

Perancangan kontrol MOSFET synchronous buck converter agar bisa mengontrol switching pada MOSFET dengan menambahkan logic NOT pada sisi bawah MOSFET. Perancangan tersebut bertujuan agar sisi MOSFET atas dan sisi MOSFET bawah tidak aktif bersamaan waktu yang sama. Jika kedua MOSFET diaktifkan secara bersamaan maka akan terjadi hubungan singkat dari tegangan masukan langsung ke ground dan menyebabkan kegagalan pada sistem penurunan tegangan.

Pada efisiensi daya yang dihasilkan synchronous buck converter disistem PV lebih baik dibandingkan dengan efisiensi daya non-synchronous buck converter. Efisiensi daya yang dihasilkan pada synchronous buck converter disistem PV ialah mencapai $98.47 \%$, sedangkan efisiensi daya yang dihasilkan pada non-synchronous buck converter disistem PV lebih rendah ialah $96.81 \%$. Ini membuktikan bahwa MOSFET dapat mengurangi rugi konduksi pada konverter DC karena rugi daya konduksi MOSFET yang lebih rendah dari rugi daya konduksi dioda.

\section{Daftar Notasi}

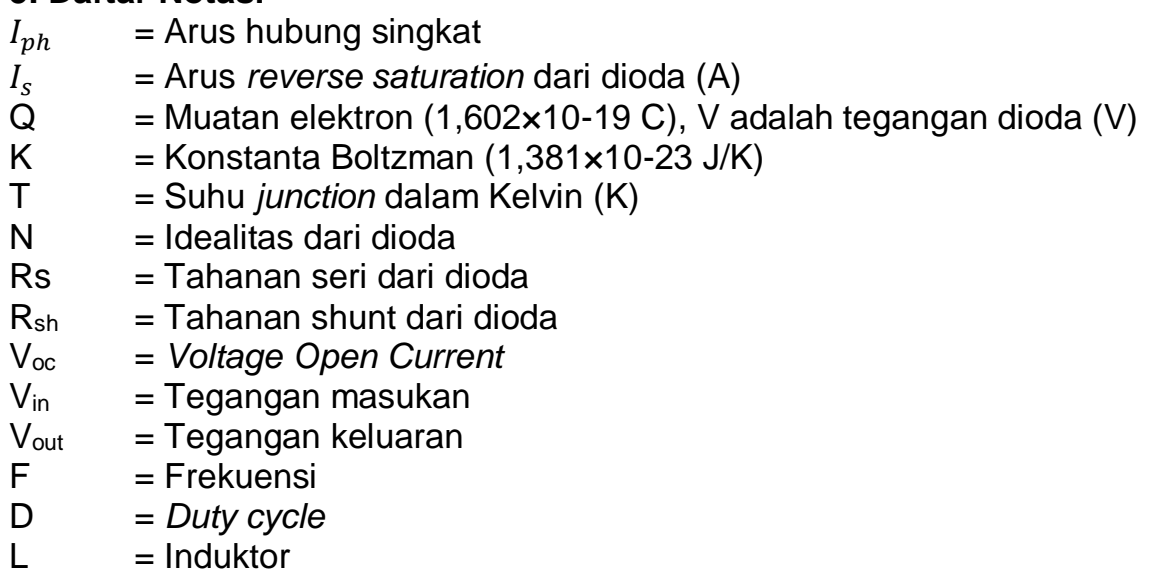

KINETIK Vol. 2, No. 3, Agustus 2017: 151-164 


$\begin{array}{ll}\mathrm{C} & =\text { kapasitor } \\ \mathrm{R} & =\text { Resistor } \\ \mathrm{VF} & =\text { Voltage Forward } \\ \Delta \mathrm{LL} & =\text { Riak arus } \\ \Delta \mathrm{vo}_{\mathrm{o}} & =\text { Riak tegangan keluaran } \\ \eta & =\text { Efisiensi daya } \\ \mathrm{R}_{\mathrm{ds}(\mathrm{on})} & =\text { Resistance Drain Source }\end{array}$

\section{Referensi}

[1] D. C. Ratna Saxena, Anmol, "DC-DC Buck-Converter for MPPT of PV System," International Journal of Emerging Technology and Advanced Engineering, 2014.

[2] S. Nema, R. Nema, G. Agnihotri, "Matlab/simulink based study of photovoltaic cells/modules/array and their experimental verification," International journal of Energy and Environment, Vol. 1, Vo. 3, 2010.

[3] A. Babgei, "Rancang Bangun Maximum Power Point Tracker (MPPT) pada Panel Surya Dengan menggunakan metode Fuzzy," Institut Teknologi Sepuluh November, Surabaya, 2012.

[4] I. Astra, S. Sidopekso, "Studi rancang bangun Solar Charge Controller dengan indikator arus, tegangan dan suhu berbasis mikrokontroler ATMEGA 8535," Universitas Negeri Jakarta. Jakarta. Spektra: Jurnal Fisika dan Aplikasinya, Vol. 11, No. 21, 2011.

[5] M. Hasan, Umar, Ir. Dedid Cahya H., "Sistem Charging Baterai Pada Perancangan Mobil Hybrid," Politeknik Negeri Surabaya.

[6] E. Taddy, V. Lazarescu, "Modeling and simulation of a switch-mode synchronous buck converter," Politehnica University of Bucharest, Bucharest, Romania, 2014.

[7] A. Darmawansyah, "Analisis Dan Perancangan Integrated Circuit AND OR Invert (AOI) Berteknologi HCMOS (High Speed Complementary Metal Oxide Semiconductor)."

[8] D. M. Sutedjo, Zaenal Efendi, "Rancang Bangun Modul DC-DC Converter Dengan Pengendali PI," Politeknik Elektronika Negri Surabaya.

[9] L. Shi, W. Jia, "Mode-Selectable High-Efficiency Low-Quiescent-Current Synchronous buck DC-DC Converter," Xidian Univesity, 2013.

[10] N. Joseph, "Control and Analysis of Synchronous Rectifier Buck Converter for ZVS in Light Load Condition," Dayananda Sagar Academy of Technology and Management, 2013.

[11] M. Romadhon, T. Andromeda, M. Facta, "Konverter Arus Searah Ke Arus Searah Tipe Penaik Tegangan Dengan Dan Tanpa Mosfet Sinkronisasi," Departemen Teknik Elektro, Universitas Diponegoro Semarang, 2016. 
